\title{
From Patagonia to Indonesia: plant fossils highlight West Gondwanan legacy in the Malesian flora
}

\author{
Peter Wilf \\ Department of Geosciences, Pennsylvania State University, \\ University Park, Pennsylvania 16802 USA; email: pwilf@psu.edu
}

\begin{abstract}
Rainforests with the chinquapin Castanopsis and the yellowwood conifer Dacrycarpus occur today throughout Indonesia and the larger Malesian ecoregion, but they represent, in part, a history of survival stretching tens of millions of years and thousands of kilometers to the paleo-Antarctic. Unlike New World and African tropical rainforests, the Malesian flora's history is closely tied to tectonic introductions from exotic terranes, and thus, much paleobotanical data about the origins of the Malesian rainforest comes from those terranes. For example, South America, Antarctica, and Australia remained adjacent until the Eocene final separation of Gondwana, and warm climates promoted high-latitude dispersals among those landmasses. Australia's subsequent northward movement led to the late Oligocene Sahul-Sunda collision and the uplift of New Guinea, allowing the introductions into Malesia of survivor taxa that were once widespread in mesic Gondwanan rainforests. In Patagonian Argentina, the prolific Laguna del Hunco (52.2 Ma) site preserves abundant and well-preserved fossils of an unexpectedly large number of lineages whose living relatives characteristically associate in perhumid, lower montane "oak-laurel" rainforests of Malesia, especially in New Guinea.
\end{abstract}

Copyright (C2021. FOSI. All rights reserved.

A Special Publication of abstracts and extended abstracts from the conference in honor of the retirement of Prof. Yahdi

Zaim, IPU (22-23 March 2021).

DOI: $10.51835 /$ bsed.2021.47.3.367 
These taxa include the angiosperms Castanopsis (Fagaceae), Gymnostoma (rhu, Casuarinaceae), Alatonucula (extinct engelhardioid Juglandaceae), Eucalyptus (gums, Myrtaceae), Ceratopetalum (coachwood, Cunoniaceae), Lauraceae (laurel family), and Ripogonum (supplejack, Ripogonaceae); conifers in Cupressaceae (cypress family: Papuacedrus), Araucariaceae (dammars and relatives: Agathis and Araucaria Section Eutacta), and Podocarpaceae (yellowwoods: Dacrycarpus, Podocarpus, and a species similar to Phyllocladus); and the fern Todea (king fern, Osmundaceae). Many of these records are the only occurrences of the respective taxa in South America, living or fossil, vastly extending their past ranges and thus the biogeographic history of part of the Malesian mountain flora. The living-fossil taxa inhabit, and several dominate, critical watershed areas of high endemism and biodiversity in Malesia's endangered tropical-montane rainforests. In Malesia itself, there have been very few Cenozoic paleobotanical investigations for about a century or more. To remedy this situation and improve understanding of the evolution of the Malesian flora in situ, we have begun paleobotanical fieldwork in collaboration with Professor Yahdi Zaim and ITB, along with international colleagues. So far, we have discovered several promising new fossil sites in the Eocene-Oligocene of West Sumatra (Sangkarewang and Sawahlunto formations) and South Kalimantan (Tanjung Formation), and I will report preliminary observations.

Keywords: Malesia, Malesian flora, rainforest, West Gondwana, Cenozoic paleobotany 